\title{
7. Debates, Town-Hall Meetings and Media Interviews
}

\author{
Geoffrey Craig
}

The issue of leaders' debates - their frequency, themes and formats - assumed key prominence in the political jockeying that occurred between Julia Gillard and Tony Abbott during the 2010 Australian election campaign. The uncertainty over the leaders' debates at times descended into farcical brinkmanship but it also underlined the political importance of debates in campaigns. The eventual hosting of two town-hall meetings late in the campaign, while not debates, represented a significant change in the recent history of the narratives of Australian election campaigns where a single televised debate has been held early in the campaign. The campaign was characterised by an unprecedented focus on the 'meta-campaign' - the influence of campaign managers, or the socalled 'faceless men', and the Prime Minister's declaration she was ditching the 'risk-averse orthodoxy of modern campaigning' — and the tortuous 'debate about the debates' contributed to an undue emphasis on campaign strategy.

While election campaigns are awash with media interviews, this chapter also focuses on interviews on high-profile national television and radio current affairs programs that play a major role in the establishment of the news agenda during election campaigns. Specifically, the monitored television programs were Insiders, 7.30 Report, Q\&A, Lateline, Four Corners, Meet the Press, Insight, A Current Affair, Today Tonight, Sunrise and Today. The monitored radio programs were $A M$ and $P M$ on the $\mathrm{ABC}$ and the Alan Jones Breakfast Show on 2GB (Sydney).

\section{Leaders' Debates}

The leaders' debate on 25 July at the National Press Club was generally judged to be uninspiring and in accord with many of the now established conventions in leaders' debate. The underdog, Tony Abbott, benefited from his participation in the debate and exceeded low expectations, establishing himself as a potentially viable prime ministerial candidate. Commentators lambasted the lacklustre content and the careful presentation of the leaders: 'The so-called positions adopted by the contestants during the televised debate added up to 
nothing more than regurgitated press releases with even less detail...They are as packaged as plastic wrapped cheese, and their careful marketing ensures they are as bland' (Wright 2010).

No new policies were announced during the leaders' debate, but a number of issues were canvassed including economic management, health, immigration, broadband, the paid parental-leave scheme and climate change.

Lyndal Curtis on $A M$ noted that while both political leaders provided disciplined performances, the advantage of the leaders' debate was that 'for most voters it would have been their first chance to see the leaders' messages in full, not sliced and diced into the bite-size quotes seen in the media' (Curtis 2010). Although some commentators observed that the debate was a relatively even contest, the so-called 'worm' - measuring the responses of a panel of undecided voters on Channel Nine - gave the debate to Gillard, 63 to 37 per cent. Channel Seven deployed its 'polligraph', which is based upon a sample of voters across the political spectrum and different demographics. A novel feature of the use of the different viewer-response measurement systems was the breakdown into responses from women and men. On Channel Nine, women voted Gillard the winner of the debate, 66 to 34 per cent, while the men voted Gillard the winner, 61 to 39 per cent.

There was much media commentary about the timing of the leaders' debate and it was eventually rescheduled so it would not coincide with the screening of the final episode of the popular MasterChef program. The MasterChef finale attracted an average capital-city audience of 3.962 million viewers, but the debate also attracted interest, with more than 3.4 million viewers across the three free-to-air networks and the ABC (Bodey 2010).

The leaders' debate ended with Tony Abbott requesting further debates, following the Rudd Government's initial promise to hold three debates during the election campaign. Over subsequent weeks in the campaign there was a series of vacillations over participation in further debates and debate formats. Prior to the leaders' debate, the Prime Minister said there would be only one debate and brushed off calls for further debates, noting she had debated Abbott many times during their regular joint appearances on the Today breakfast program and elsewhere. After a poor second week of campaigning for the Labor Party, the Prime Minister took up an offer on the Today Tonight program on the Seven Network to debate the Opposition Leader on the subject of the economy, but Abbott then refused the offer. Paul Kelly (2010b) noted that the Opposition Leader's refusal to debate on the economy, after calling for further debates, was risky and arrogant, and Peter van Onselen (2010) also noted it was a missed opportunity. The challenges and accusations about a debate on the economy continued to dog the campaign but it was agreed that a town-hall-style 
forum, with separate appearances from the two leaders taking questions from the public, would take place on Wednesday, 11 August. Subsequently, Abbott agreed to a debate on the economy, but wanted to restrict it to a 30-minute debate on the ABC, while the Prime Minister called for an hour-long debate. The stand-off, culminating in the final week of the campaign, was not resolved, leaving a frustrated Kerry O'Brien (2010) to ask the Opposition Leader: 'Tony Abbott, do you accept that for many Australian voters, this spat about a debate that's chewed up so much energy on both sides must by now look like a couple of immature kids exchanging insults in the schoolyard?'

The farcical debate about the election campaign debates strongly emphasises the need for the establishment of a debate commission, similar to the bipartisan Commission on Presidential Debates that oversees the US presidential campaign debates. Such a commission would be a valuable instrument in a bid to depoliticise the issue of leaders' debates and ensure that valuable campaign energy would not be wasted on strategic positioning by the party leaders. The Opposition Leader pledged that if elected he would establish such a commission, and the Prime Minister has subsequently included the issue of a debates commission in her agreement with the Greens Party (Brown 2011).

There were also a number of other debates of various formats that featured during the election campaign. The customary series of National Press Club debates occurred between ministers and their shadows on areas such as the economy, foreign affairs, health and communications. The debate format extended to breakfast television, with the Sunrise program on Channel Seven featuring debates between Wayne Swan and Joe Hockey on the economy, and also debates between The Nationals and the Greens, and the Australian Sex Party and the Family First Party.

Another unusual feature was the hosting of a leaders' debate outside the formal election campaign on 23 March after the then Prime Minister, Kevin Rudd, accepted a challenge from Tony Abbott during a parliamentary exchange. The debate, on health policy and held at the National Press Club, was offered by the government as one of three leaders' debates. Although the apparently snap decision to have a debate seemed initially a risky strategy for the Prime Minister, the debate demonstrated the advantage of incumbency, with Rudd able to choose the debate topic on which he was able to expound on his recent work on hospitals policy. The debate unfolded as a quite lively exchange between the two participants. Barrie Cassidy (2010) noted: 'It was a very good debate... by historical standards. At times, the leaders actually engaged one another directly, contrary to the rules.' Rudd performed well and was generally judged to be the winner of the debate. Paul Kelly (2010a) wrote: 'This debate was a throwback to the confident Rudd of the 2007 campaign. It should delight Labor strategists.' In accord with previous experiences in leaders' debates, the deployment of a 
positive approach contributed to debate success; Rudd's invocation of his family background and his use of personal and homespun language were favourably received by the so-called 'worm' that recorded the responses of a panel of undecided voters.

\section{Town-Hall Meetings}

A highlight of the election campaign was the hosting of two town-hall meetings or 'community forums' (the events were promoted as the People's Forum) where both the Prime Minister and the Opposition Leader were separately subject to an hour of questions from an audience of uncommitted voters, selected by the Galaxy polling company. The first town-hall meeting, on Wednesday, 11 August, at the Rooty Hill RSL Club in western Sydney, featured aggressive questioning of Gillard on a number of subjects, including the dumping of Kevin Rudd, gay marriage, pensions and climate change. There was particular scepticism from the audience when Gillard talked about ALP advertisements that cited Peter Costello's criticisms of Tony Abbott's economic credentials, and also when the Prime Minister talked about a proposed rail link between Parramatta and Epping in Sydney that was announced earlier that day. The Prime Minister attempted to stress the government's competence in management of the economy throughout her appearance. This was underlined in her opening remarks when she asked for members of the audience to raise their hands if they had a mortgage or if they paid rent, and then asked those people to keep their hands raised if they could continue to make those payments if they did not have a job.

Abbott received a more favourable response from the audience, although he did receive some questions that were critical of his party's position on asylumseekers and broadband policy. As one journalist noted: 'The audience took a more inquisitive line with Abbott, less interested in the finer details of policies and more keen for him to elucidate who he was' (Welch 2010). Abbott appeared more comfortable than Gillard with the audience, and was able to deploy effectively the populist form of discourse required of such a format, which was supported by his decision to speak from the forum floor, on the same level as his interrogators. The town-hall meeting bolstered the fortunes of the Opposition. The Australian reported:

In a spirited and confident performance at a venue where he once boxed, the Opposition Leader marked himself as a man at ease in the suburbs and a leader who would not only listen, but would solve their problems: from health to congestion, drug abuse to the rising cost of living. (Dusevic and Maher 2010) 
The mix of questions and the modes of delivery from voters at times provided a welcome contrast with the conventional, well-honed cut and thrust of news media interviews. The general predilection of the audience to favour Abbott did prompt some subsequent public discussion about the selection process for the forum, and this discussion received momentum when it was discovered that one of Abbott's questioners was the son of a former SA Liberal MP (Coorey 2010a).

The second town-hall meeting was held on Wednesday, 18 August at the Broncos Leagues Club in Brisbane, just days before the election. The forum, held amid the wrangling over a debate over the economy, was a more even affair, and the Prime Minister was judged to be the winner with 83 votes to 75 votes for Abbott (Coorey 2010b). The Brisbane town-hall meeting attracted more viewers than the earlier event in Sydney, which was restricted to pay television viewers, although neither town-hall meeting was screened by the commercial television networks. The Opposition Leader, speaking first, again took to the forum floor, stating 'this is an exchange, not a lecture', and the Prime Minister followed his lead and also spoke at the same level as her questioners. The more equal approaches to the leaders in the second forum was reflected in a contrast between the opening questions for the Opposition Leader in the two meetings: in Brisbane he was asked a challenging question about affordable housing and the cost of living and the Opposition Leader acknowledged his limited ability to effect change, while the initial questioner at the Rooty Hill town-hall meeting provided Abbott with an easy opportunity to exploit a political advantage when he was asked a question on climate change. The Opposition Leader was asked about a range of issues including apprenticeships, superannuation, abortion, medical research, pension increases, peak oil, computers in schools, drought assistance, Aboriginal disadvantage, and gay marriage. Indeed, Abbott received 27 questions in the Brisbane town-hall meeting - considerably more than a week earlier in Sydney. Going against the convention of such public events, the Opposition Leader flagged a new policy where students could help pay off their Higher Education Contribution Scheme (HECS) debt by doing volunteer work. The Prime Minister was again questioned several times about the ousting of Kevin Rudd. She was also asked questions about medical negligence, desalination plants, medical registration systems, death duties and capital gains tax, education policy, the budget surplus, refugees, broadband and the Resource Super Profits Tax.

The town-hall meetings were generally welcomed in the 2010 election as campaign events that would provide greater opportunity for members of the public to express their views. In this way, such meetings were responses to the increasing party control of election campaigns that had sidelined public engagement with their political leaders. As Paul Kelly (2010c) wrote after the second forum: 'These events in Brisbane and Rooty Hill should establish the 
town hall concept as basic to future election campaigns.' Although questions did often reflect the mainstream news agenda, the town-hall meetings did permit a broad variety of questions, and their expression by members of the public helped to personalise and embody particular public issues. The meetings also required both party leaders to use a more accessible discourse in their answers, and the events facilitated greater accountability than sometimes occurs in conventional media interviews. As Channel Seven political editor, Mark Riley (2010), said in his preview of the Brisbane meeting: 'They can expect some unscripted questions from real people that they'll have to answer unlike at press conferences when they avoid our questions entirely.'

In addition to these town-hall meetings, the election campaign also featured forum-style programs that provided members of the public with an opportunity to question the party leaders and other politicians. The $Q \& A$ program on the $A B C$ featured singular separate performances by both Abbott and Gillard in the last two weeks of the election campaign, and earlier programs during the campaign featured a panel of participants. The SBS program Insight was also based on questions and comments from members of the public, although it featured a regular group of uncommitted voters from a range of marginal seats across the country. Both programs also built into their structure questions and comments from other members of the public through online program sites, Facebook posts and tweets (Twitter). Q\&A, for example, ran tweets in a banner at the bottom of the screen as ongoing responses to the studio discussion. Similarly, Insight drew on reports from an online reporter who summarised Facebook debates. Inclusion of such online and social media responses further enhanced the dialogic nature of such programs, distinguishing them from conventional political television that largely excludes the public.

\section{Media Interviews}

Media interviews constitute the prime form of political communication in election campaigns, and the 2010 Australian election in particular was characterised by a blitz of such encounters. In the last couple of days of campaigning, the leaders of both the major parties conducted dozens of radio and television interviews although most were merely short recitations of well-worn campaign messages. There were, nonetheless, a significant number of interviews throughout the campaign that had an important effect on the shaping of the campaign narrative and these extended, formal interviews are the subject of discussion here. In addition, both party leaders and senior members of the Labor, Liberal, National and the Greens parties were frequently interviewed throughout the campaign across most of the monitored programs. 
An early interview in the campaign was a performance by the Prime Minister on 60 Minutes. The interview mixed policy discussion with a more human-interest inquiry into the character and life of Julia Gillard. In addition to questions on the change of leadership, trade union influence on the Labor Party and the war in Afghanistan, Gillard was also asked about her mother and her partner. The Prime Minister also tried to diminish the policy differences between Labor and the Coalition on asylum-seekers in an early bid to defuse the subject as an election issue.

Media interviews are forums where political leaders can promote their individual character, personality and 'life story', but they are also prime opportunities for political opponents to seize upon gaffes, any hesitation or prevarication, or any deviation from previously articulated views. In the first week of the campaign, Tony Abbott's attempt to remove the spectre of WorkChoices from the campaign was first illustrated in a media stunt in a 3AW (Melbourne) radio interview where he signed a 'contract' guaranteeing it would not return as Liberal Party policy, but then in subsequent remarks he stated: 'Obviously, I can't give an absolute guarantee about every single aspect of workplace relations legislation, but WorkChoices is gone, now and forever.' This statement provided the Labor Party with the opportunity to continue its claim that WorkChoices, or some form of it, might be resurrected by a Coalition government.

It was indicative of the muted impact of the leaders' debate that an interview of Tony Abbott by Kerry O'Brien on the 7.30 Report on the following evening did not make mention of the debate. In a lively exchange, $\mathrm{O}^{\prime}$ Brien questioned Abbott's economic management skills with reference to Peter Costello's previous comments about the Liberal Party leader, and he challenged the Coalition's stance on future immigration levels. In an unusual move, O'Brien also screened an extended excerpt from an interview with Abbott a year earlier in which the then Opposition frontbencher indicated a willingness to revisit the industrial relations policies of the previous Coalition government.

The Prime Minister was caught out the following day in an interview with Alan Jones on $2 \mathrm{~GB}$ when she stumbled on naming the year that lower company tax rates would be introduced. The Prime Minister engaged in a lengthy process of stalling as she apparently sought an answer to Jones's question. It was also at this time, during the second week of the campaign, that it was observed that Gillard's 'favourability' rating with talkback calls around the country was falling (Elliott 2010). It was also during this week of the campaign, however, that the Australian Women's Weekly featured an extended interview and photo shoot with the Prime Minister. The article reflected more general news media interest in the personality and personal life of the new Prime Minister. While much of the 
news media reportage presented the persona of Gillard favourably, the matters of her de-facto relationship, her childlessness and her lack of religious faith were also subject to public discussion in both the tabloid and the quality media.

A significant amount of news media attention during the campaign focused on former Prime Minister Kevin Rudd, the circumstances of his ousting and the nature of his relationships with the woman who succeeded him as prime minister and his senior Labor Party colleagues. The third week of the campaign featured an interview of Rudd by Phillip Adams on the $\mathrm{ABC}$ radio program Late Night Live where the former Prime Minister, fresh from his gall-bladder surgery, declared that he would be campaigning for the Labor Party outside his electorate and that he did not want Tony Abbott 'sliding into office by default'. Rudd also recorded an interview with the Seven Network's Sunday Night program that screened later in the campaign, on 15 August.

Another interview that had an impact on the campaign narrative was an interview of Tony Abbott by Kerry O'Brien on the 7.30 Report in the following week of the campaign, on 10 August. In the interview, O'Brien quizzed the Opposition Leader on the broadband policy that had been released by the Liberal Party earlier in the day and Abbott several times acknowledged his limited technical knowledge in the area: 'Again, if you're gonna get me into a technical argument, I'm going to lose it, Kerry, because I'm not a tech head' (ABC 2010). This less than convincing performance by Abbott contributed to subsequent journalistic scrutiny of both the Opposition's broadband policy and the Opposition Leader's command of technology and economic policy detail.

The final week of the campaign featured a number of major interviews of the major-party leaders in addition to the daily frenetic campaigning and major campaign events, including the Brisbane town-hall meeting and the late delivery of the Labor Party campaign 'launch'. On ABC Television, both major-party leaders were featured in an episode of Four Corners and both completed their third interviews on the 7.30 Report. On commercial television, both Gillard and Abbott conducted interviews on A Current Affair.

\section{Conclusion}

The 2010 Australian election campaign offered a strong contrast between the blandness of a highly disciplined leaders' debate and the more informal, unpredictable and informative series of town-hall meetings. The debate throughout the campaign about the number and format of leaders' debates highlighted the need for pre-existing agreement about leaders' debates that could be facilitated through a debates commission. While we should always expect the performances of political leaders to be highly disciplined in debates, 
interviews and other media performances, the greater public involvement that occurred through the town-hall meetings and forum-style programs required party leaders to offer less-scripted responses across a broad range of issues, to appear more human and less combative. The campaign also emphasised the ongoing importance of media interviews to both scrutinise political performance and provide significant public platforms on which politicians can promote their own political and personal narratives. The character of the next Australian election campaign will be strongly influenced by the political uncertainty that arises from a minority government but hopefully it might also be shaped by recognition of the benefits of greater opportunities for public involvement and at least some questioning of the overwhelming influence of the 'risk-averse orthodoxy of modern campaigning'.

\section{References}

Australian Broadcasting Corporation (ABC). 2010. 7.30 Report, 10 August, ABC TV, viewed 11 August 2010, <http://www.abc.net.au/7.30/content/2010/ s2979381.htm>

Bodey, Michael. 2010. 'MasterChef tops 3.9m but debate not far behind'. The Australian, 26 July, viewed 26 July 2010, <http://www.theaustralian. com.au/business/media/masterchef-tops-39m-but-debate-not-far-behind/ story-e6frg996-1225896908998>

Brown, Bob. 2011. 'PM confirms commitment on leader's debates'. The Australian Greens. 15 April, viewed 13 December 2011, <http://bob-brown.greensmps. org.au/content/media-release/pm-confirms-commitment-leaders-debates $>$

Cassidy, Barrie. 2010. 'Positivity the best policy as Rudd tweets ahead'. The Drum, 23 March, viewed 24 March 2010, <http://www.abc.net.au/ news/stories/2010/03/23/2853911.htm>

Coorey, Phil. 2010a. "Jobs" Julia grilled as Tony leads from front'. Sydney Morning Herald, 12 August, 6.

Coorey, Phil. 2010b. 'Abbott pledges to slash debt'. Sydney Morning Herald, 19 August, 1.

Curtis, Lyndal. 2010. 'Debate produces no clear winner'. AM, 26 July, ABC Radio, viewed 26 July 2010, <http://www.abc.net.au/am/content/2010/ s2963851.htm>

Dusevic, Tom and Maher, Sid. 2010. 'People warm to a leader at their level'. The Australian, 12 August, 1. 
Elliott, Geoff. 2010. 'PM's radio ratings in a downward spiral'. The Australian, 28 July, 5.

Kelly, Paul. 2010a. 'Rudd skates home with sweetreason'. The Australian, 24 March, viewed 24 March 2010, <http://www.theaustralian.com.au/news/opinion/ rudd-skates-home-with-sweet-reason/story-e6frg6zo-1225844495756>

Kelly, Paul. 2010b. 'Abbott's rejection of debate betrays risky arrogance'. The Australian, 5 August, 1.

Kelly, Paul. 2010c. 'Julia improves, but Tony is a natural'. The Australian, 19 August, 5.

O'Brien, Kerry. 2010. 'Abbott gears up for election day'. 7.30 Report, 17 August, ABC TV, viewed 18 July 2010, < http://www.abc.net.au/7.30/content/2010/ s2985780.htm>

Riley, Mark. 2010. Channel Seven News, 18 August.

van Onselen, Peter. 2010. 'It's the economy, stupid, but let's not talk about it' . The Australian, 7-8 August, 14.

Welch, Dylan. 2010. 'Getting down to the nitty-gritty at Rooty Hill RSL'. Sydney Morning Herald, 12 August, 6.

Wright, Tony. 2010. 'Abbott and Gillard as packaged as plastic-wrapped cheese'. Sydney Morning Herald, 26 July, viewed 26 July 2010, <http://www.smh. com.au/federal-election/abbott-and-gillard-as-packaged-as-plasticwrappedcheese-20100726-10r88.html> 